\title{
New contribution to the reproductive features of bluemouth Helicolenus dactylopterus dactylopterus from the northeast Atlantic (Azores Archipelago)
}

\author{
ANA MENDONÇA ${ }^{1}$, EDUARDO ISIDRO ${ }^{1}$, GUI MENEZES ${ }^{1}$, MÁRIO RUI PINHO ${ }^{1}$, \\ OCTÁVIO MELO ${ }^{1}$ and SUSANA ESTÁCIO ${ }^{2}$. \\ ${ }^{1}$ Departamento de Oceanografia e Pescas, Universidade dos Açores, Cais de Santa Cruz, 9901-862 Horta, Portugal. \\ E-mail: amendonca@notes.horta.uac.pt \\ ${ }^{2}$ Direcção Regional das Pescas dos Açores, Rua Consul Dabney, 9900-014 Horta, Portugal.
}

\begin{abstract}
SUMMARY: This work describes and identifies the macroscopic and corresponding microscopic changes of the gonads of an important commercial fish species, Helicolenus dactylopterus dactylopterus, from Azores Archipelago. The new contribution relates the macroscopic scale with the histological stages. The annual changes in the gonad, together with the analysis of the monthly gonadosomatic indices, and complementary observations with scanning electron microscopy, allow us to conclude that the females are internally inseminated between July and November and spawn between January and March. There is a separation between female and male reproductive cycles. The overall sex-ratio observed was 1:1, but seasonal and length related differences were observed. This suggests differences and changes in availability, probably related to the annual reproductive cycle and changes in feeding behaviour
\end{abstract}

Keywords: Helicolenus dactylopterus dactylopterus, northeast Atlantic, reproduction, histology, maturity stages.

RESUMEN: NUEVA CONTRIBUCIÓN A LAS CARACTERÍSTICAS REPRODUCTIVAS DEL HELICOLENUS DACTYLOPTERUS DACTYLOPTERUS EN El ATLÁNTICO NORESTE (ARCHIPIÉLAGO DE AZORES). - Este trabajo describe e identifica las etapas de madurez macroscópicas y correspondientes etapas microscópicas de las gónadas de una especie comercial importante, Helicolenus dactylopterus dactylopterus, de la pesquería del archipiélago de las Azores. La nueva contribución relaciona la escala macroscópica con las etapas histológicas. Los cambios anuales de las gónadas, junto con el análisis de los índices gonadosomáticos y con las complementarias observaciones con microscopía electrónica (SEM), permiten concluir que las hembras son inseminadas internamente entre julio y noviembre y desovan entre enero y marzo. Hay una separación entre los ciclos reproductivos de las hembras y los machos. En general la proporción sexual es 1:1; pero desviaciones de esta proporción fueron registradas estacionalmente y para para ciertas clases de talla. Estas desviaciones sugieren diferencias y cambios en la disponibilidad, relacionadas probablemente con los cambios reproductivos anuales y con el comportamiento alimentario.

Palabras clave: Helicolenus dactylopterus dactylopterus, Atlántico noreste, reproducción, histología, etapas de madurez.

\section{INTRODUCTION}

The bluemouth, Helicolenus dactylopterus (Delaroche, 1809), belongs to the Sebastidae family and is wide spread in the Atlantic Ocean. Eschmeyer (1969) reported four populations for the Atlantic from the subspecies Helicolenus dactylopterus dactylopterus: north-east Atlantic (including North Africa, Canaries, Madeira and Azores), Mediterranean, the Gulf of Guinea, South Africa, and the north-west Atlantic. This species is considered bentonic (Whitehead et al., 1986) and in the Azores the commercial captures of this species are located between the depths 150 and $600 \mathrm{~m}$ (Isidro, 
1989). During the scientific cruises along the Azores archipelago this species had peak abundance around $500 \mathrm{~m}$ (Menezes, 2003).

In this region the longline demersal fishery is a multispecies fishery involving more than 20 species and represents the second most important fishery in economic revenue in the Azores archipelago (Silva et al., 1994; Krug, 1995). Helicolenus dactylopterus (bluemouth) has been exploited in the Azores (ICES area $\mathrm{X}$ ) at least since the XVI century as part of the demersal fishery, and is currently one of the largest northeast Atlantic fisheries (Pinho, 2003; Anon., 2004). This species is also consistently the most frequently caught during the spring Azorean demersal surveys (Pinho, 2003).

In Azores, the regular longline annual monitoring surveys onboard R/V Arquipélago over the last years have been an important way to study the exploited demersal species. These cruise surveys were very important for collecting biological material and studying the ecology of these species. One of the routine works in these cruises is classifying gonads using macroscopic scale. Some problems were detected during the cruises related to lack of clarity in the distinction between some of the gonadal stages. For this reason the seasonal changes in reproduction where studied on a regular basis. Macroscopic staging is a practical and quick method in field work, but validation by histology is necessary to ensure data quality. Determining the sex ratio and the sequence of changes in maturity stages during the year are of considerable importance in building up a thorough knowledge of the general biology of an exploited stock. These form part of the basis of stock assessment (Holden and Raitt, 1974).

The information on bluemouth reproduction includes two studies from the Azores (Isidro, 1989; Estácio et al., 2001), other studies from the Atlantic (Kelly et al., 1999; Sequeira et al., 2003; White et al., 1998) and mainly studies from the Mediterranean Sea (Allain and Lorane, 2000; Muñoz et al., 1999; Muñoz et al., 2000; Muñoz et al., 2002a,b,c;). Isidro (1989) focuses on reproduction and growth of this species while Estácio et al. (2001) concentrate on sex-ratio and size and age at first maturity. Several works of Muñoz et al. (1999; 2000; 2002a,b,c) describe in detail the structures for sperm storage inside the ovaries, the histochemical analyses of sperm storage, the gametogenesis, reproductive indices and fecundity in the western Mediterranean. Sequeira et al. (2003) recorded embryonic stages in the intraovarian "gelatinous matrix". White et al. (1998) collected baseline lifehistory information for the western Atlantic using histology to determine reproductive stages. Kelly et al. (1999) showed some maturity data for the eastern Atlantic. However, they had some difficulties with the macroscopic scale used.

To estimate spawning stock biomass it is necessary to know the proportion of mature females in each age group so a cautious identification of the mature fish is necessary. This is the first work that concentrates on validation/calibration of a macroscopic maturity scale for this species using histology. An imagery database that facilitates identifying the different stages will be provided. This work will contribute with new data on the reproductive biology of $H$. dactylopterus dactylopterus.

\section{MATERIALS AND METHODS}

The data used in this study came from two sources: the seasonal longline surveys and from the commercial fishery (Table 1). The fishing gear used by both these sources was the same, i.e. bottom longline.

Seasonal surveys were made on board $\mathrm{R} / \mathrm{V}$ "Arquipelago" during spring, summer and autumn of 1999. The spring survey, which is a standard annual survey, covered the entire Azores Archipelago around islands, banks and major seamounts (Fig. 1). The summer and autumn surveys only covered the statistical areas of the central group of islands. The surveys followed a standard stratified design by statistical areas and depth strata (24 strata from 50 to $1200 \mathrm{~m}$ ). Stations within each area were selected randomly (see Pinho, 2003 for standard survey sampling details). All fishes caught were tallied by species and strata, measured (total length recorded to the $\mathrm{cm}$ below) and weighed (to the nearest gram). Information on length, weight, sex, maturation stage, gonad and liver weight, was recorded according to species and depth strata.

TABLE 1. - Data sources.

\begin{tabular}{lccc}
\hline Quarter & Surveys & Commercial Fishery & Total \\
\hline Winter & - & 132 & 132 \\
Spring & 719 & 99 & 818 \\
Summer & 232 & 142 & 374 \\
Autumn & 153 & 126 & 279 \\
\hline
\end{tabular}




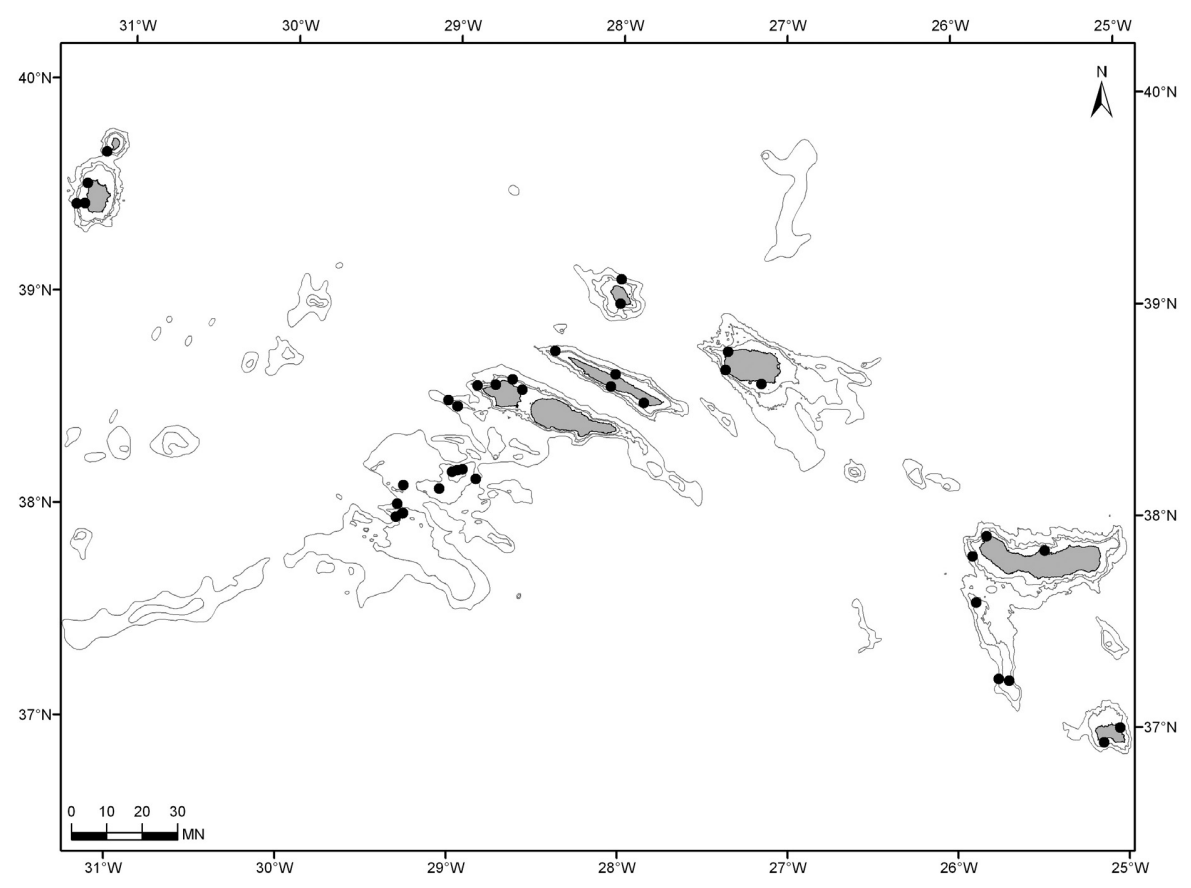

FIG. 1. - Map of sampling sites.

Commercial longline fishery samples for the central group of islands, from 1997 to 2000, were collected through the regional landing sampling program conducted by the University of the Azores. Biological sampling methods followed the survey sampling protocol.

TABLE 2. - Scale used to determine maturity stages for $H$. dactylopterus dactylopterus females based on macroscopic and microscopic examination of the ovaries (adapted from White et al 1998).
Stages Macroscopic and microscopic description of the ovaries

0, Immature The gonads are small and translucent.

Primary or previtelogenic oocytes only.

II, Developing The gonads are opaque, consistent, with some vascularization, the oocytes are scarcely visible, with rose colour.

Oocytes yolked undergoing through vitellogenesis, with yolk granules on the cytoplasm.

III, Pre-spawning The gonads are opaque, consistent, with a vascularization well developed, the oocytes are well visible, oocytes with orange, rose or white colours.

Oocytes in a final maturation usually with a migratory nucleus and coalescence of yolk material.

IV, Spawning The gonads are opaque, consistent, with a vascularization well developed, the hydrated oocytes are well visible, forming a gelatinous matrix well visible with orange, rose or white colours.

Hyaline oocytes or evidence of hyaline oocytes

V, Spent The gonads are opaque, flaccid, with some vascularization, sometimes some residual oocytes visible, with a reddish colour.

Atretic oocytes (the ovaries were only classified as atretic when a large percentage of yolked oocytes were atretic, or when atretic oocytes were accompaied only with unyolked oocytes).

I, Resting The gonads are opaque, consistent, with some vascularization, the oocytes are not visible, with a reddish to rose colour.

Primary and unyolked oocytes usually at the start of yolk vesicle accumulation. 
TABLE 3. - Scale used to determine maturity stages for males based on macroscopic and microscopic examination of the testes (Adapted from White et al, 1998)

\begin{tabular}{|c|c|}
\hline Stages & Macroscopic and microscopic description of the testes \\
\hline \multirow[t]{2}{*}{0, Immature } & The gonads are small and translucent. \\
\hline & $\begin{array}{l}\text { Small transverse section compared to resting male; spermatogonia and little or no spermatocyte development; } \\
\text { sperm ducts and main spermatic duct not as evident as in resting stage. }\end{array}$ \\
\hline \multirow[t]{2}{*}{ II, Developing } & The gonads are large, consistent and white \\
\hline & Development of cysts containing spermatogonia in mitosis, spermatocytes and spermatids \\
\hline \multirow[t]{2}{*}{ III, Pre-spawning } & The gonads are consistent, well developed, white and with visible sperm \\
\hline & Containing cysts in all stages of development, spermatozoa in sperm ducts and in main spermatic duct \\
\hline \multirow[t]{2}{*}{ IV, Spawning } & The gonads are wihitish in colour, with very visible sperm that run when abdomen is pressed. \\
\hline & Perdominance of spermatozoa in sperm ducts and in main spermatic duct, little or no occorence of spermatogenesis. \\
\hline \multirow[t]{2}{*}{ V, Spent } & The gonads are opaque, flaccid, with "bloody aspect" and with some sperm \\
\hline & $\begin{array}{l}\text { Some residual spermatozoa in sperm ducts and main spermatic duct, ocorrence of spermatogonia and development } \\
\text { of conjunctive tissues }\end{array}$ \\
\hline \multirow[t]{2}{*}{ I, Resting } & The gonads are small, whitish or grey in colour, sometimes with residual sperm. \\
\hline & $\begin{array}{l}\text { Large transverse section compared with immature male, little or no spermatocyte development, begining of } \\
\text { spermatogonia activity, empty sperm ducts, sometimes residual spermatozoa is still visible. }\end{array}$ \\
\hline
\end{tabular}

ferent maturation stages were also photographed using a digital camera and an image database was constructed in order to be used in future field work.

Two methods were used for the microscopic examination of gonads: light microscopy and scanning electron microscopy (SEM). The first was used to validate the macroscopic scale and the SEM was used with the aim of understanding the sperm storage in the ovaries better.

For light microscopy, the gonads were fixed with BOUIN, dehydrated, embedded in paraffin wax, then sectioned ( $5 \mu \mathrm{m}$ cross sections) and stained with the general coloration hematoxylin-eosin following the method adapted from Costa and Chaves (1943). A six-stage maturity scale based on microscopic characteristics that matches the macroscopic scale better was used to classify the maturity stage of females and males (Table 2 and Table 3 ).

In order to validate the macroscopic scale we compared the frequencies of occurrence of different maturity stages classified macroscopically and microscopically.

For scanning electron microscopy (SEM) small pieces of ovaries were fixed with $2.5 \%$ glutaraldehyde in $0.1 \mathrm{M}$ sodium cacodylate buffer $(\mathrm{pH}$ 7.2) for 4 to 6 hours. Samples were washed with $0.2 \mathrm{M}$ sodium cacodylate buffer for 1 to 2 hours, dehydrated in ethanol 30\% (20 minutes), 50\% (20 minutes) and kept at $70 \%$. This material was frozen with liquid nitrogen and cracked with a razor blade (criofracture). The cracked tissue blocks were then returned to $70 \%$ ethanol. The samples were critical point dried with liquid carbon dioxide. They were then mounted on metal stubs and coated with carbon and gold. They were observed with JEOL (JSM-5410) scanning electron microscopy at different voltages $(15-30 \mathrm{kV})$.

The overall ratio of females to males was determined and tested by chi-square analysis (Zar, 1999). Sex-ratios (females:males) were determined as described in González et al. (2003). In addition, sex-ratios (females:males) for each season and length class were calculated. Data from the length classes were grouped into two categories, before and after $28 \mathrm{~cm}$ length (juveniles and adults). $28 \mathrm{~cm}$ is the length of first maturity for all individuals determined by Estácio et al. (2001) for this specie in this region. The GSI and HSI (weight of the organs/total weight) were determined for each sex and were calculated following King (1995).

\section{RESULTS}

Of a total of 1642 specimens examined, 776 were females $(47.3 \%)$ and 827 were males $(50.4 \%)$. The sex of the remaining 39 individuals $(2.4 \%)$ could not be determined. Tables 4 and 5 present the results for the observed sex-ratio according to quarter and size class. The overall sex-ratio observed was $1: 1\left(\chi^{2}=\right.$ $1,62 ; \mathrm{df}=1 ; \mathrm{P}>0.05)$ but seasonal and length related differences were observed. In the winter (Table 3) 
TABLE 4. - Number of females (F) and males (M) by quarter; sex ratio tested by $\chi^{2}$ - analysis $\left(\chi^{2}\right)$.

\begin{tabular}{lcccc}
\hline Quarter & F & M & Sex-ratio & Significance \\
\hline Winter & 53 & 79 & $1: 1.49$ & $\mathrm{P}<0.05$ \\
Spring & 391 & 427 & $1: 1.09$ & $\mathrm{P}>0.05$ \\
Summer & 179 & 195 & $1: 1.09$ & $\mathrm{P}>0.05$ \\
Autumn & 153 & 126 & $1: 0.82$ & $\mathrm{P}>0.05$ \\
\hline
\end{tabular}

TABLE 5. - Number of females (F) and males $(\mathrm{M})$ by 2-cm size class: sex ratio tested by $\chi^{2}$ - analysis $\left(\chi^{2}\right)$. [* Size class not size classe]

\begin{tabular}{lcccr}
\hline $\begin{array}{l}\text { Size classe } \\
(\text { TL, cm })\end{array}$ & F & M & Sex-ratio & Significance \\
\hline 14 & 1 & 2 & $1: 2$ & $\mathrm{P}>0.05$ \\
16 & 5 & 8 & $1: 1.6$ & $\mathrm{P}>0.05$ \\
18 & 11 & 7 & $1: 0.64$ & $\mathrm{P}>0.05$ \\
20 & 34 & 24 & $1: 0.71$ & $\mathrm{P}>0.05$ \\
22 & 57 & 39 & $1: 0.68$ & $\mathrm{P}>0.05$ \\
24 & 70 & 55 & $1: 0.79$ & $\mathrm{P}>0.05$ \\
26 & 121 & 80 & $1: 0.66$ & $\mathrm{P}<0.05$ \\
28 & 93 & 96 & $1: 1.03$ & $\mathrm{P}>0.05$ \\
& & & & \\
$\leq 28$ & 392 & 311 & $1: 0.79$ & $\mathrm{P}<0.05$ \\
30 & 114 & 123 & $1: 1.08$ & $\mathrm{P}>0.05$ \\
32 & 92 & 97 & $1: 1.05$ & $\mathrm{P}>0.05$ \\
34 & 78 & 82 & $01: 05$ & $\mathrm{P}>0.05$ \\
36 & 50 & 64 & $1: 1.28$ & $\mathrm{P}>0.05$ \\
38 & 30 & 65 & $1: 2.17$ & $\mathrm{P}<0.05$ \\
40 & 13 & 54 & $1: 4.15$ & $\mathrm{P}<0.05$ \\
42 & 6 & 23 & $1: 3.83$ & $\mathrm{P}<0.05$ \\
44 & 0 & 6 & - & - \\
46 & 0 & 2 & - & - \\
48 & 1 & 0 & - & - \\
& & & & $\mathrm{P}$ \\
$>28$ & 384 & 516 & $1: 1.34$ & $\mathrm{P}<0.01$ \\
Total & 776 & 827 & $1: 1.07$ & $\mathrm{P}>0.05$ \\
\hline
\end{tabular}

significant differences from the 1:1 ratio were found $\left(\chi^{2}=5,12 ; \mathrm{df}=1 ; \mathrm{P}<0.05\right)$. Different sex-ratio trends with the length and statistically significant differences from the 1:1 ratio were observed (Table 4). In

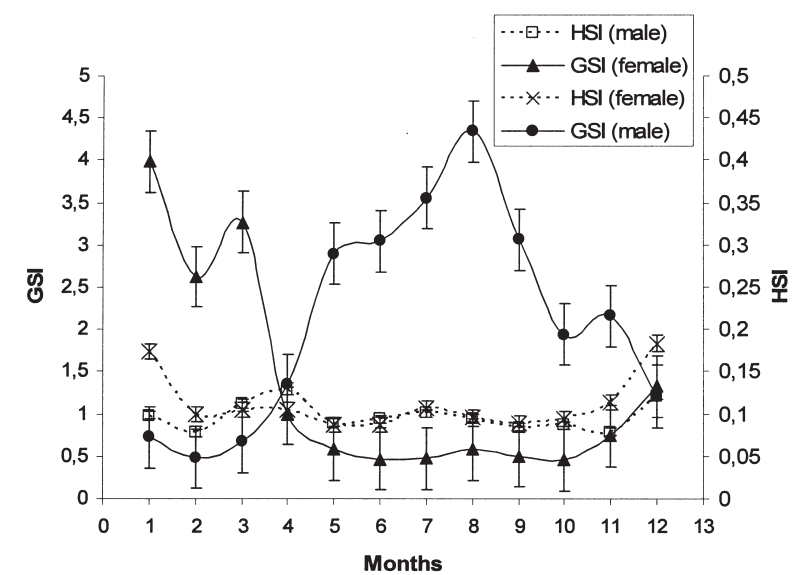

FIG. 2. - Monthly averaged values (with error bars) of the gonadosomatic index (GSI) and hepatosomatic index (HSI) for females GSI (N=703) and HIS (N=660) - and for males - GSI (N=648) and HIS (N=654).
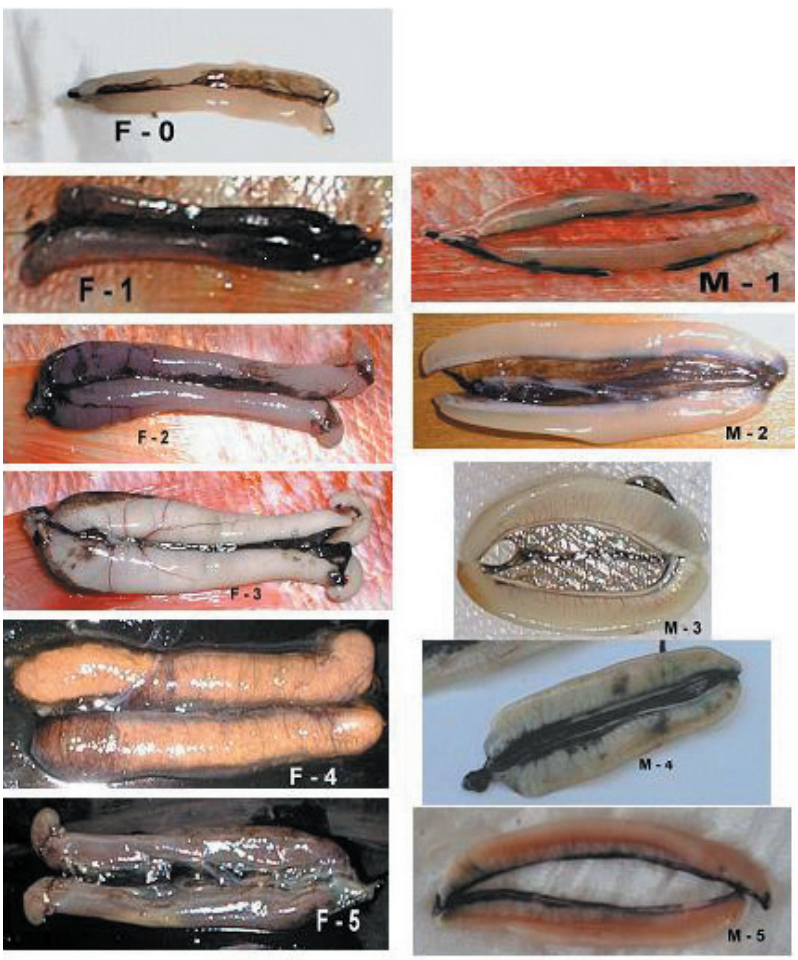

FIG. 3. - Macroscopic aspects of some maturity stages of females and males of $H$. dactylopterus dactylopterus: $\mathbf{F - 0}$ : female in stage 0 of maturity; F-1: female in stage I of maturity; $\mathbf{F - 2}$ : female in stage II of maturity; F-3: female in stage III of maturity; F-4: female in stage IV of maturity; F-5: female in stage V of maturity; M-1: male in the stage I of maturity; M-2: male in the stage II of maturity; $\mathbf{M -}$ 3: male in the stage III of maturity; M-4: male in stage IV of maturity; M-5: male in stage $\mathrm{V}$ of maturity.

general there were statistically significant differences in the length class of $26 \mathrm{~cm}\left(\chi^{2}=8,36\right.$; $\mathrm{df}=1$; $\mathrm{P}<0.05)$ with predominance of females and in the length classes of 38,40 and $42 \mathrm{~cm}\left(\chi^{2}=12,89 ; \chi^{2}=\right.$ 25,$09 ; \chi^{2}=9,97$ respectively $\left.\mathrm{df}=1 ; \mathrm{P}<0.05\right)$ with predominance of males. When these data were grouped into two categories (before $\left(\chi^{2}=9,33\right.$; $\mathrm{df}=1 ; \mathrm{P}<0.05)$ and after $\left(\chi^{2}=19,36 ; \mathrm{df}=1 ; \mathrm{P}<0.01\right)$ $28 \mathrm{~cm}$ in length) statistically significant differences were observed in the sex proportions (Table 5).

The evolution of the monthly GSI for females (Fig. 2) revealed the maximum values between January and March and the minimum values between May and October. For males (Fig. 2) the maximum values of the GSI occurred between May and October and the minimum between January and March. It is interesting to note that the maximum values of female GSI correspond to the minimum values of male GSI and the minimum values for females correspond to the maximum values for males.

The monthly HSI for females (Fig. 2) reaches maximum values between December and January 

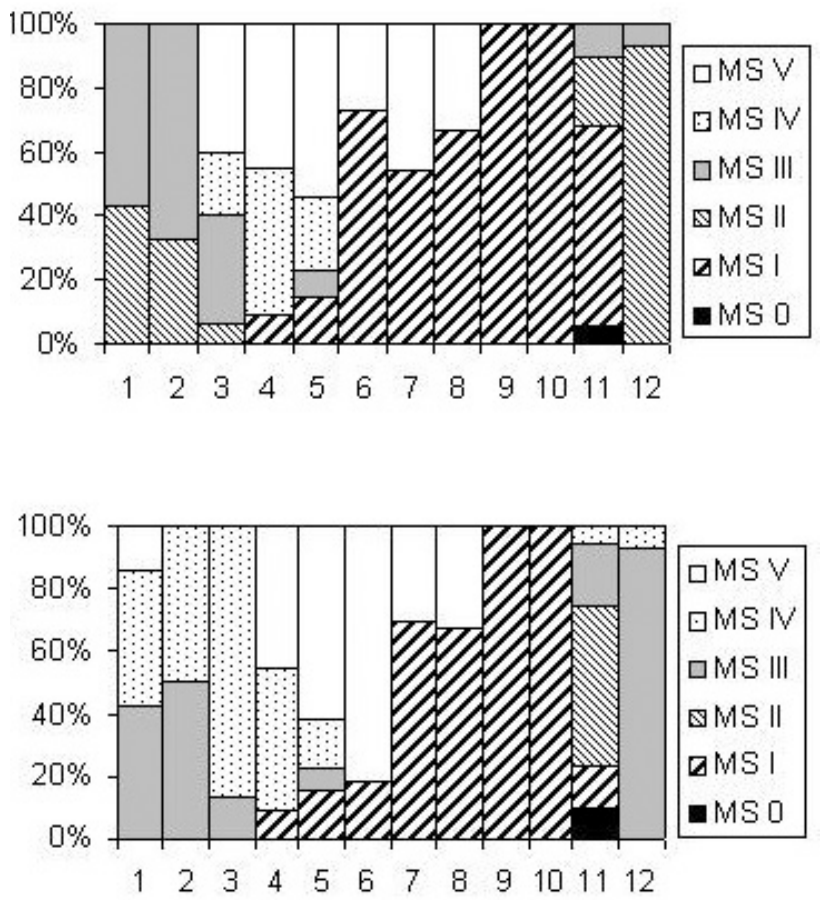

Months

FIG. 4. - Monthly changes of the percent frequency of the maturity stages classified macroscopically (up) and microscopically (down) for females.
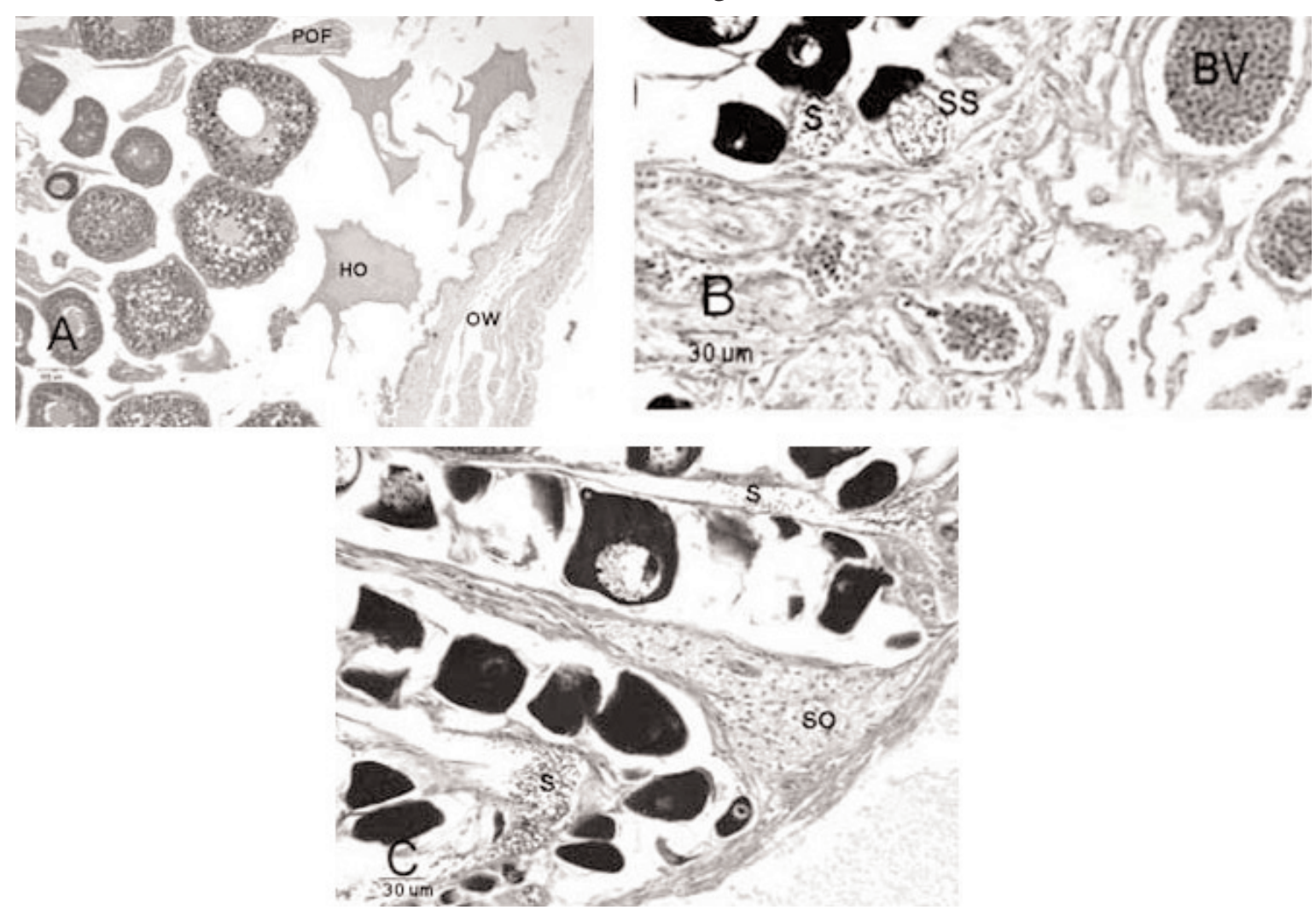

FIG. 5. - Some histological aspects of the ovaries of $H$. dactylopterus dactylopterus A, ovary in the ripe stage (stage IV) with evidence of hydrated oocytes and post-ovulatory follicles; $\mathbf{B}$, ovary with spermatozoa in a sperm storage structure near the base of ovarian septum; C, ovary with large accumulation of free spermatozoa. (OS, ovarian septum; SS, sperm storage structure; S, spermatozoa; BV, blood vessel; OW, ovarian wall; PO, previtellogenic oocytes; HO, evidence of hydrated oocytes; POF, post-ovulatory follicles). and remains relatively constant in the rest of the year. For males the maximum HSI values were obtained in April and December (Fig. 2).

Photo identification of most of the maturity stages is presented in Figure 3. Females in mature stages were present from November until May and the resting stages predominate between June and November (Fig. 4). The same sample of 183 females was classified microscopically and some differences were noted. Comparing the two classifications it seems that, macroscopically, stage II was confounded with stage III, and stage III with stage IV (Fig. 4). All six maturation stages of the ovaries were identified (Fig. 5).

Males in the mature stages were present from April to December (only a small percentage) while the resting stages predominated between December and March. The same sample of 171 males was classified microscopically and some differences were noted. In the months of February and March some individuals entered development stage II and more individuals were classified in stage III from April to August (Fig. 6). Based on the observation of histological sections in a mature male it can be seen that 


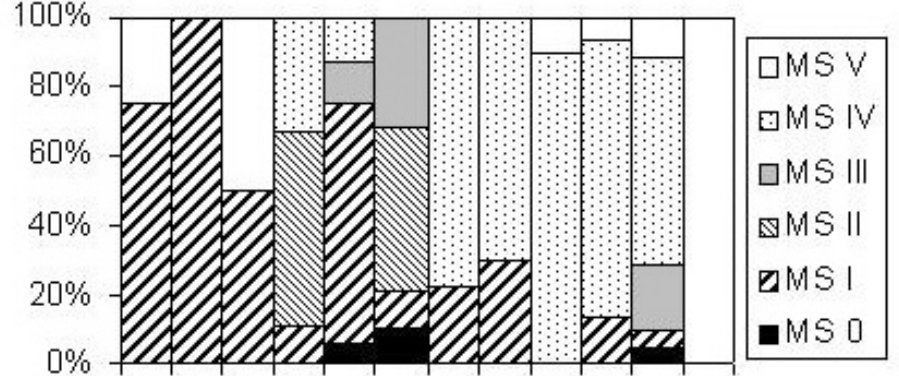

$\begin{array}{llllllllllllll}1 & 2 & 3 & 4 & 5 & 6 & 7 & 8 & 9 & 10 & 11 & 12\end{array}$

Months

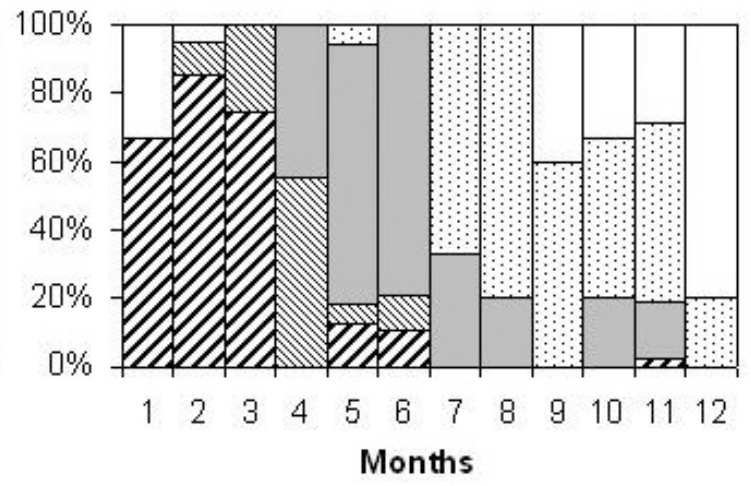

FIG. 6. - Monthly changes of the percent frequency of the maturity stages classified macroscopically (right) and microscopically (left) for males.

the lumen of sperm ducts and of the main spermatic duct is almost exclusively spermatozoa (Fig. 7).

In all the months a concentration of spermatozoa in the base of the ovarian septum can be observed. These concentrations of spermatozoa are inside a structure for sperm storage described by Muñoz et al. (2000). The scanning electron microscopy study carried out confirmed the existence of spermatozoa within structures even in the post-spawning stage of ovaries (Fig. 8). However, free spermatozoa (unattached) were also observed in the ovaries between July and November. The histological sections ana-
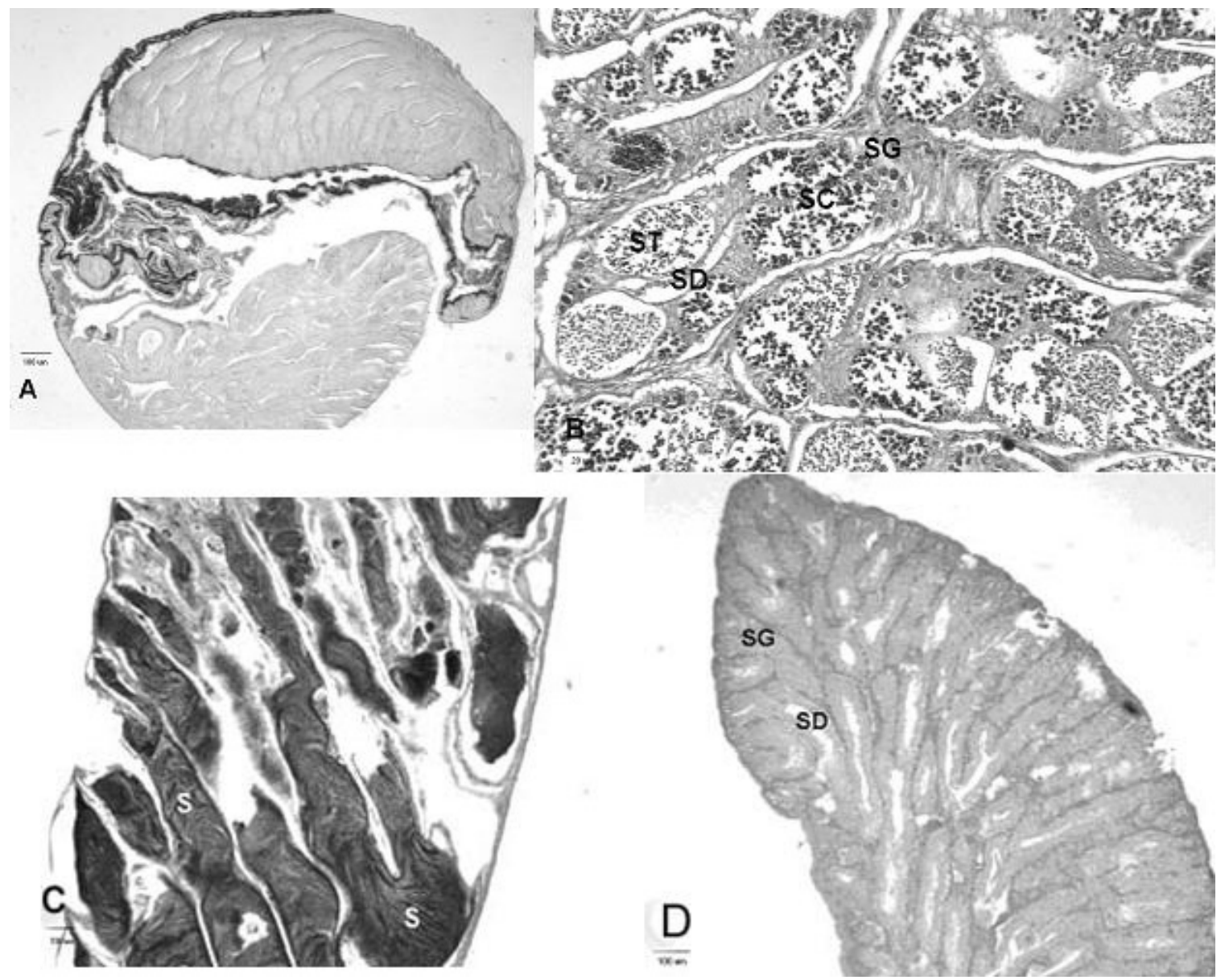

FIG. 7. - Some histological aspects of the testes of H. dactylopterus dactylopterus: A, testes from an immature male (stage 0); $\mathbf{B}$, testes with an evident spermatogonial activity and with cysts in various stages of development (stage II); $\mathbf{C}$, testes full of spermatozoa and with very low spermatogonial and spermatogenic activity (stage IV); D, testes from a resting stage (stage I) showing the empty sperm ducts and the beginning of spermatogonial activity. (SG, spermatogonia; S, spermatozoa; SC, spermatocytes; ST, spermatids; SD, sperm ducts; MD, main spermatic duct.) 

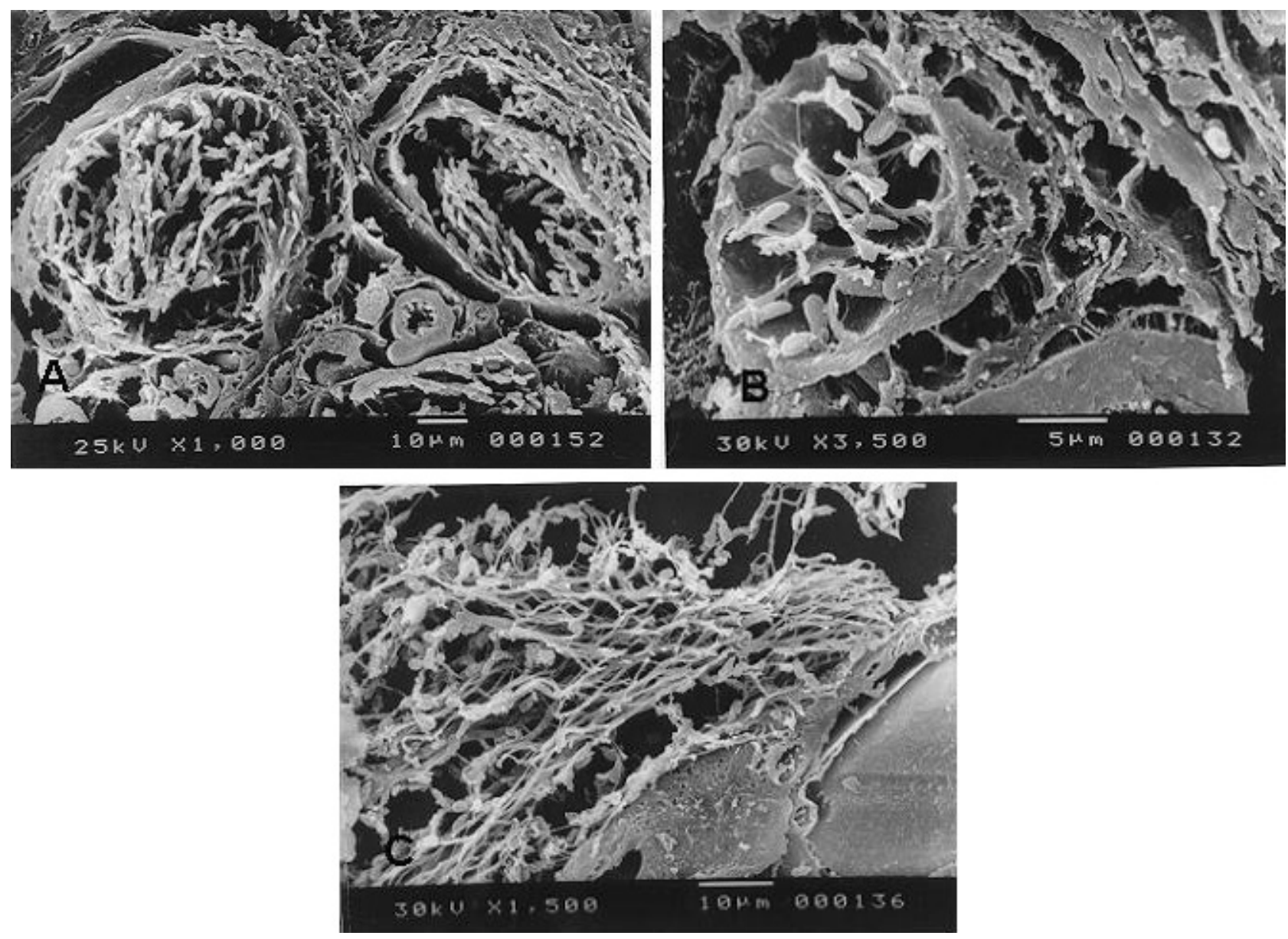

FIG. 8. - Details of the internal structure of the ovary of $H$. dactylopterus dactylopterus: A, view of a sperm storage structure with spermatozoa near the base of ovarian septum; $\mathbf{B}$, different view of a sperm storage structure with spermatozoa; $\mathbf{C}$, detail showing the accumulation of free spermatozoa near the base of the ovarian septum (Scanning Electron photomicrograph).

lyzed in this period contained evidence of internal fertilization, as free spermatozoa were observed in resting or developing ovaries with a peak occurrence between September and November.

\section{DISCUSSION}

In general the sex-ratio remains close to equity, but in winter a significant difference from the 1:1 ratio was observed, with males predominating in the catches. These results are consistent with Isidro (1989) and it is interesting to note that the winter period matches the female spawning period. This suggests that there is a difference in the availability of both sexes for the fishery. This may be because of a spatial segregation of sexes or because of different behaviour in relation to the gear, probably a feeding behaviour, when a baited gear is used. The existence of a difference in feeding behaviour between sexes, related to the onset of first maturity and to the annu- al reproductive cycle, is reinforced by the analysis of sex-ratios according to length classes. The data show that before the onset of first maturity (length at which all fish are mature $=28 \mathrm{~cm}$ ) more females are caught and after this point the sex proportion in the catches is inversed. Our results are consistent with White et al. (1998) who stated that males were more abundant than females at lengths up $250 \mathrm{~mm}$. The overall sex-ratio is in accordance with Muñoz and Casadevall (2002a) obtained for Mediterranean specimens where the sex-ratio remains close to equity. However, in this study we observed differences in terms of size in relation to sex. For the Azores, Esteves et al. (1997) did not find important differences in growth between sexes; nevertheless, the von Bertalanffy growth rates for females and males are different.

The results of the GSIs and of the macroscopic and microscopic stages are consistent for the spawning period and indicate that this species spawns from January to March. The same spawning period was 
observed by Isidro (1989) and by Estácio et al. (2001), and is also reported for other geographic areas, for instance the SE coast of the United States (White et al., 1998). In addition, a study by Sobrinho-Gonçalves and Isidro (2001) for Azores found larvae of this species mainly in February and March.

There is a separation between female and male reproductive cycles. The females are internally inseminated between July and November. This suggests that females retain the sperm inside the ovaries for a period that may reach 6 to 7 months. White et al. (1998) also described a delay of 1 to 3 months between insemination and fertilization and Muñoz et al. (1999) reported periods of up to ten months. This reproductive characteristic was also suggested by Isidro (1989). The sperm cells remain viable right up to the moment of fertilization and spawning (Muñoz et al., 1999). Muñoz et al. (2000) suggested that there is an ovarian contribution of nutrients. With light microscopy it was observed that in the histological sections of the ovaries, there were concentrations of spermatozoa near the ovarian septa. These concentrations appeared to be (are) inside a structure for sperm storage. Similar observations were made by White et al. (1998) and these structures were extensively described by Muñoz et al. (1999). A different approach using scanning electron microscopy confirmed the existence of spermatozoa either within structures or free in the inter-septa space. These structures, which contain spermatozoa, were observed in every month and where present even in the ovaries in a post-spawning stage. The period where free spermatozoa were observed in the ovaries was similar to that recorded by White et al. (1998). This author registered the occurrence of early cell embryos in the females' ovaries. A new approach was used by Sequeira et al. (2003) that confirmed the existence of embryos in various development stages but most of all in the early-celled stage. In this study no embryos were observed in the histological sections of the ovaries analyzed, but many of the pre-spawning eggs within the "gelatinous matrix" observed in the ovaric lumen were systematically lost along the histological processing.

Using histology also allowed the macroscopic scale to be calibrated. It does not seem necessary to include extra stages, and the different stages are now described (Table 2 and 3 ) and illustrated better (Fig. 4).

\section{ACKNOWLEDGEMENTS}

This research was supported by the European Commission (D.G. XIV/C/1-Study Contract 97/081). We also wish to thank our colleagues José Branco, Domitília Rosa, Ana Fernandes, Ângela Canha, Dália Reis and all the others that participated in the survey cruises onboard R/V Arquipélago. A special thanks to Jorge Medeiros for his support with scanning electron microscopy and to Ricardo Medeiros for his help with the map figure. We are grateful to Dr. John Hales for the English review. Also supported by ORPAM 2 Project / INTERREG - III-B/ FEDER.

\section{REFERENCES}

Allain, V. and P. Lorance. - 2000. Age estimation and growth of some deep-sea fish from the Northeast Atlantic Ocean. Cybium, 24(3) suppl.: 7-16.

Costa, A.C. and P.R. Chaves. - 1943. Manual de técnica histológica. Portugália, Lisboa.

Estácio, S., A. Mendonça, H.M. Krug, G.M. Menezes, J. Branco and M.R. Pinho. - 2001. Aspects of the reproduction of six demersal species captured in the Azores archipelago. Arquipélago, Life Mar. Sci., 2B: 83-94.

Eschmeyer, W.N. - 1969. A systematic review of the scorpion fishes of the Atlantic Ocean (Pisces:Scorpaenidae). Occ. Papers Calif Acad. Sci., 79: 1-130.

Esteves, E., J. Aníbal, H.M. Krug and H.M. Silva. - 1997. Aspects of age and growth of bluemouth, Helicolenus dactylopterus dactylopterus (Delaroche, 1809) from the Azores. Arquipélago. Life M. Sci., 15A: 83-95.

González, J.A., V. Rico, J.M. Lorenzo, S. Reis, M. Afonso Dias, A. Mendonça, H.M. Krug and M. Pinho. - 2003. Sex and reproduction of the alfonsino Beryx splendens (Pisces, Berycidae) from the Macaronesian archipelagos. J. Appl. Ichthyol., 19(2): 104-108.

Holden, M.J. and D.F.S. Raitt. - 1974. Manual of Fisheries Science, Part 2 - Methods of Resource Investigation and their Application. FAO, Rome.

Anon. - 2004. Report of the Working Group on the Biology and Assessment of Deep Sea Fisheries Resources. ICES CM 2004/ACFM:15RefG, Copenhagen.

Isidro, E. J. - 1989. Crescimento e reprodução de Helicolenus dactylopterus (Delaroche, 1809). Relatório no âmbito das Provas de Aptidão de Acesso à categoria de Assistente de Investigação, Universidade dos Açores (Departamento de Oceanografia e Pescas), Horta, Faial, Açores.

Kelly C.J., P.L. Connoly, and J.J. Bracken. - 1999. Age estimation, growth, maturity, and distribution of the bluemouth rockfish Helicolenus $d$. dactylopterus (Delaroche, 1809) from the Rockall Trough. ICES J.Mar. Sci., 56: 61-74.

King, M. - 1995. Fisheries Biology, Assessment and Management. Fishing News Books, Blackwell Scientific Ltd, Oxford, England.

Krug, H.M. - 1995. Biologia e avaliação do stock açoreano de goraz, Pagellus bogaraveo. Ph. D. thesis, Univ. of the Azores, Portugal.

Menezes, G. - 2003. Demersal Fish Assemblages in the Atlantic Archipelagos of the Azores, Madeira, and Cape Verde. Ph. D. thesis, Univ. of the Azores, Portugal.

Muñoz, M., M. Casadevall and S. Bonet. - 1999. Annual reproductive cycle of Helicolenus dactylopterus dactylopterus (Teleostei:Scorpaeniformes) with special reference to the ovaries sperm storage. J. Mar. Biol. Assoc. U.K., 79: 521-529.

Muñoz, M., M. Casadevall, S. Bonet and I. Quagio-Grassiotto. - 
2000. Sperm storage structures in the ovary of Helicolenus dactylopterus dactylopterus (Teleostei:Scorpaeniformes): an ultrastructural study. Env. Biol. Fishes, 58: 53-59.

Muñoz, M. and M. Casadevall. - 2002a. Reproductive indices and fecundity of Helicolenus dactylopterus dactylopterus (Teleostei:Scorpaeniformes) in the Catalan Sea (Western Mediterranean). J. Mar. Biol. Assoc. U.K., 82: 995-1000.

Muñoz, M., M. Casadevall and S. Bonet. - 2002b. Gametogenesis of Helicolenus dactylopterus dactylopterus (Teleostei: Scorpaeniformes). Sarsia, 87: 119-127.

Muñoz, M., Y. Koya and M. Casadevall. - 2002c. Histochemical analysis of sperm storage in Helicolenus dactylopterus dactylopterus (Teleostei:Scorpaeniformes). J. Exp. Zool., 292: 156-164.

Pinho, M. R. - 2003. Abundance estimation and management of Azorean demersal species. Ph. D. thesis, Univ. of the Azores, Portugal.

Sequeira, V., I. Figueiredo, M. Muñoz and L.S. Gordo. - 2003. New approach to the reproductive biology of Helicolenus dactylopterus. J. Fish Biol., 62: 1206-1210.
Silva, H.M., H.M. Krug and G.M. Menezes. - 1994. Bases para a Regulamentação da Pesca de demersais nos Açores. Arquivos do DOP - Série Estudos (4/94), Universidade dos Açores.

Sobrinho-Gonçalves, L. and E. Isidro. - 2001. Fish larvae and zooplankton biomass around Faial island (Azores archipelago). A preliminary study of species occurrence and relative abundance. Arquipélago. Life Mar. Sci., 18A: 35-52.

White, D.B., D.M. Wyanski and G.R. Sedberry. - 1998. Age, growth, and reproductive biology of the blackbelly rosefish from the Carolinas, U.S.A. J. Fish Biol., 53: 1274-1291.

Whitehead, P.J.P., M.L. Blanchot, J.C. Hureau, J. Nielsen and E. Tortonese. - 1989. Fishes of the North-eastern Atlantic and Mediterranean, UNESCO, volume III, Paris.

Zar, J.H. - 1999. Biostatistical Analysis. Fourth Edition. PrenticeHall International Editions, New Jersey.

Received September 28, 2005. Accepted March 31, 2006.

Scient. ed.: E. Massutí.

Published online November 15, 2006. 